\title{
Body Weight Gain Test Code
}

National Cancer Institute

\section{Source}

National Cancer Institute. Body Weight Gain Test Code. NCI Thesaurus. Code C119778.

A character or string that represents the short code name of the body weight gain assessment. 